\title{
Michael Desmond Rickard
}

$(1941-2019)$

Michael or Mike to everyone was born in India, where his father was an officer serving in the British Army during the Second World War. After the war the family returned to Liverpool. They then migrated to New Zealand in 1949, when Mike was eight years old. Mike followed his older brother Brian by enrolling in veterinary science at the University of Queensland. He graduated BVSc in 1963 with first class honours and a University Medal for outstanding academic excellence. Mike then undertook a PhD in the Department of Parasitology headed by Professor John Sprent, under the supervision of John and Colin Dobson, working on the carbohydrate metabolism of Babesia rodhaini in mice, graduating in 1967.

That year, Mike was appointed Lecturer in Veterinary Parasitology at Massey University in New Zealand. In 1969 he moved to the University of Melbourne, Faculty of Veterinary Science, as a Senior Lecturer in Parasitology. At Melbourne, Mike began a program of research on immunity to the larval stages of taeniid cestodes, prompted by a political ban imposed by the USA on the importation of Australian sheep meat due to the presence of cysticerci of Taenia ovis. Such was trade at the time, American sheep were infected with the same parasite but its presence in Australian sheep meat was used as an excuse for the ban. In 1971, Mike published a seminal paper showing that larvae of Taenia ovis and T. taeniaeformis confined in diffusion chambers in the peritoneal cavity of their intermediate hosts (sheep and rats respectively) induced immunity to challenge with infective eggs.

This research overturned the accepted wisdom of the time that immunity to metazoan parasites could only be achieved in some cases after direct exposure to living parasites. Mike's laboratory eventually identified the proteins associated with the development of immunity, and developed the first genetically engineered vaccine against a parasite (Taenia ovis). It was celebrated as one of the "Milestones in Parasitology" in 1993, although commercialisation was fraught with difficulty and following normalisation of trade with the USA.

Apart from his major interest in taeniid cestodes, Mike also collaborated in diverse areas, such as the life cycles of protists (Sarcocystis), other cestodes (Anoplotaenia in Tasmanian devils) and gastrointestinal nematodes of ruminants (Camelostrongylus). He also supervised a number of PhD students including Ian Beveridge, Brian Coman, Phil Craig, David Bowtell, David Jenkins, Henrik Bøgh and Robin Gasser, and accommodated numerous post-doctoral researchers and sabbaticants in his laboratory.

During his tenure at the University of Melbourne, Mike was awarded the degree of Doctor of Veterinary Science by the University (1979), was President of the Australian Society for Parasitology (ASP) in 1982, was awarded the BancroftMackerras medal for excellence in research by the ASP in 1983, and was elected as a Fellow of the Society in 1987. Mike was heavily involved in the bid led by Professor Sprent to host ICOPA VI in Brisbane and officially accepted the invitation from the World Federation of Parasitologists to hold the conference during the closing ceremony of ICOPA V. The ASP appointed him as the scientific programme coordinator for ICOPA VI. In 1986, Mike was elected to the Executive Board of the World Federation of Parasitologists, one of only six members from around the world.

In 1989, following an international selection process, Mike was appointed to the position of Chief of the CSIRO Division of Animal Health. This comprised the Animal Health Research Laboratory (AHRL) in Melbourne, the high-security Australian Animal Health Laboratory (AAHL) in Geelong, the McMaster Laboratory in Sydney and a group at the Pastoral Research Laboratory, Armidale, NSW. He arrived in CSIRO at a time when the Organization was going through major change following the Commonwealth Government's 1986 decisions requiring CSIRO to emphasise applications-oriented research, transfer of results to users with increased interaction with industry, and a target of $30 \%$ funding from non-government sources. With these requirements in mind, Mike immediately conducted a review of Research Programs and Priorities with the aid of external assessors he had chosen and including consultation with research staff, across the range of work in infectious, parasitic and plant-associated toxin diseases of cattle, sheep, pigs and poultry. The Division had a long history of working closely with industry but Mike led a successful concentration of effort on key projects with substantial collaboration and increased funding from industry partners. At the same time, he maintained an underpinning of strategic research in fields such as the development of recombinant bacterial and viral vaccine vectors, and into cytokines aimed at improving immune responses. During his tenure, the Division delivered or collaborated in a number of successful innovations in industry, notably the gamma-interferon-based blood test for rapid 
diagnosis of tuberculosis in cattle which is now also used world-wide in human medicine, and vaccines for infectious bursal disease in chickens and footrot in sheep.

During this period, CSIRO was experiencing cuts in direct government funding and then falls in livestock industry funding, principally from the wool industry, so that by 1994, the animal health and production Divisions would have to make very significant savings. The principle adopted was preservation of as much good research as possible by reducing overhead costs and retaining as many key staff as possible by encouraging relocations rather than redundancies. Mike's plan to deal with this unprecedented challenge for the Division of Animal Health was to close the AHRL and transfer its work on endemic diseases to AAHL in Geelong after converting the unused vaccine manufacturing facility that is outside the secure area of AAHL into new laboratories. Most of the staff at AHRL was opposed to the plan but he eventually carried it through in 1995 with a combination of thorough consultation, sound judgement and persistence. Some staff took redundancy rather than move to AAHL, some chose to commute from Melbourne, but Mike showed the way by he and Trish moving to live in Geelong with the Divisional HQ located in AAHL. The standards of the converted laboratories were assisted by Mike convincing the CSIRO Executive of the need to retain the proceeds from the sale of field station properties at Maribrynong, Werribee and Badgerys Creek. In 1995, Mike was appointed CSIRO member on the Australian and New Zealand Council for the Care of Animals in Research and Teaching (ANZCAART).

The successful transfer of the endemic diseases laboratory from Parkville to Geelong resulted in realisation of Mike's vision and plans with most of the projects and programs and their leaders and managers being relocated to the new site. This created a larger centralised, critical mass of scientists for animal disease research to enhance productivity and disease resistance. The new laboratory opened in 1997 and was central to Mike's encouragement of staff to closely collaborate with industry and commercialise their successful strengthening the research output and the creation of new opportunities to the benefit of the Australian livestock industries. A modern animal facility was also established on a new site at Werribee for the new Geelong laboratory. The collaboration between the co-located laboratories was facilitated and this was particularly evident with the protein biochemistry and proteomics project. In addition, new gene technologies (bioinformatics, microarrays, RNA interference for gene silencing, genome editing and transgenics) were incorporated in a range of projects. Collaboration with industry partners was continued with promising vaccine delivery systems using recombinant antigens and cytokines in conjunction viral and bacterial vectors. In recognition of Mike's managerial talents, he was appointed to a Task Force to develop details for CSIRO structure and operational arrangements towards the year 2000 .

In 1994, the AAH diagnostic team in collaboration with Queensland Department of Primary Industries, identified a new paramyxovirus, named Hendra virus, which caused a fatal respiratory disease affecting horses and humans. Diagnostic tests were developed and a prototype vaccine for horses was subsequently commercialised and registered. In 1995, for outstanding research in identifying the cause of this emerging disease, the research group under the leadership of Dr Keith Murray (Deputy Chief and Head of AAHL) won the CSIRO Chairman's Medal. In 1996, a new virus, Australian bat lyssavirus, closely related to exotic rabies virus was discovered by AAHL scientists. In 1998-1999, AAHL scientists formed part of a task force investigating fatalities in humans and pigs in Malaysia and were instrumental in identifying the causative agent, a new bat-borne virus, Nipah virus. Thus, during Mike's term as Chief of Animal Health, AAHL scientists from the biosecurity area had confirmed their international reputation for investigating and researching emerging animal diseases.

In his 10 years in CSIRO Animal Health after a prior distinguished personal research career, Mike showed exceptional qualities of consultative leadership in a diverse research environment combined with excellence in analytical thinking and judgement in science and in the management of people and resources. He was disappointed to leave the position of Chief of Animal Health in 2000 when CSIRO combined all of its remaining animal health and production research into a single Division of Livestock Industries but he continued to serve the Organisation as Special Advisor on Animal Welfare for ANZCAART until his retirement from CSIRO in 2005. Mike received a rarely awarded Honorary Life Membership of ANZCAART in 2012. Mike continued to work in animal welfare on State and Federal animal welfare committees that achieved the cooperation of the livestock industries in establishing uniform national standards for domestic livestock welfare.

Mike was awarded the Gilruth Prize by the Australian Veterinary Association in 2014 for outstanding service to veterinary science in Australia, and in 1991 was the recipient of the Clunies Ross Medal for Science and Technology. He also was elected a Fellow of the Australian Academy of Technology and Engineering in 1992.

Mike died unexpectedly in June; he is survived by his wife Trish, his sons Jeff and Tony, his daughter, Kylie, and four grand-children. This obituary was produced with the full knowledge of Trish Rickard. 
AJ Turner, I Beveridge, M Lightowlers, AD Donald, DF Stewart 


\section{University Library}

\section{- M M I N E R VA A gateway to Melbourne's research publications}

Minerva Access is the Institutional Repository of The University of Melbourne

Author/s:

Turner, AJ;Beveridge, I;Lightowlers, M;Donald, AD;Stewart, DJ

Title:

Michael Desmond Rickard (1941-2019).

Date:

2020-09

Citation:

Turner, A. J., Beveridge, I., Lightowlers, M., Donald, A. D. \& Stewart, D. J. (2020). Michael Desmond Rickard (1941-2019).. Aust Vet J, 98 (9), pp.471-472. https://doi.org/10.1111/ avj.13012.

Persistent Link:

http://hdl.handle.net/11343/276220 